\title{
OLIGARCHY AND DEMOCRACY IN INDONESIA
}

\author{
Jeffrey A. Winters
}

\section{Introduction}

Of all political power resources in Indonesia, material power is by far the most concentrated, versatile, durable, and least constrained. The gap in material power across the population is among the largest in the world. Data from 2010 show that the average net worth of Indonesia's forty richest oligarchs is over 630,000 times the country's GDP per capita (in Thailand and South Korea the gap is 190,000 and 69,000 times, respectively). Although these oligarchs constitute less than $2 / 1,000,000$ ths of the population, their combined assets equal 10 percent of GDP. ${ }^{1}$ Even if we widen the lens to include the 43,000 Indonesians with liquid financial assets of at least US\$1 million, the result is still an extraordinary concentration of material power resources in very few hands. ${ }^{2}$ Although these individuals represent barely $2 / 10,000$ ths of the population, on average they have at their disposal financial assets that are 1,220 times the annual income of the median Indonesian. Their combined assets equal fully 25 percent of GDP. Indonesia is following the classic pattern of capitalist development: as living

\footnotetext{
${ }^{1}$ For further comparisons, see Table 1 later in this article.

${ }^{2}$ The global wealth management industry calls these people high net-worth individuals, or HNWIs. In 2004, Indonesia had about 34,000 HNWIs with at least US\$1 million in non-home financial assets, 19,000 of whom were Indonesians residing semi-permanently in Singapore. Their ranks grew to 39,000 by 2007 . The average wealth of Indonesia's HNWIs in 2010 was US\$4.1 million, and their combined net worth was about US\$177 billion (US\$93 billion of which was held offshore in Singapore). See Capgemini, "World Wealth Report," Capgemini and Merrill Lynch, Inc., 2011; and "Forbes 40 Richest," Forbes, November 23, 2011, at www.forbes.com/lists/2011/80/indonesia-billionaires-11_land.html. Gini coefficients, which are an extremely blunt measure, compare the resources of the top fifth of society against the bottom fifth. They do not capture the extremes reported here because oligarchs make up only a fraction of the top 1 percent, and their wealth is invisible when commingled with that of the entire top 20 percent.
} 
standards at the bottom and middle of society gradually improve, a small number of ultra-wealthy citizens at the top are rapidly pulling away from the rest.

The starting point for understanding contemporary Indonesian politics is the observation that extreme material inequality necessarily produces extreme political inequality. Whether in democracies or authoritarian systems, the more unequal the distribution of wealth is, the more exaggerated the power and influence of enriched individuals becomes, and the more intensely the material gap itself colors the political motives and objectives of oligarchs. Whatever other more dispersed power resources exist across society-such as the small individual influence conferred by one-personone-vote under Indonesia's democracy, or leverage based on mobilization and direct action by activists and labor-it is this gross asymmetry in material power that shapes, dominates, and warps the country's ordinary politics. Oligarchic theory best captures the power and politics of extreme wealth concentration in Indonesia's political economy and brings into relief its role within the country's social formation.

Wealth is the most potent and flexible of all power resources for influencing political outcomes during non-crisis periods, and those who deploy wealth power have a political impact far out of proportion to their numbers in society. Although concentrated wealth profoundly shapes politics in every country, it does so to varying degrees depending on the effectiveness of limits designed to dampen its use for direct and indirect political objectives, and on the strength mustered by other actors across the political spectrum. Material power is much less reliable during major crises, disruptive periods of upheaval and violence, and episodes of high social mobilization. In these circumstances, other power resources tend to overwhelm the political influence of wealth. Except in cases where crises lead to the destruction of oligarchs themselves-as occurred in the revolutions engulfing Russia, China, Vietnam, Cambodia, and Cuba-the disruption of the wealth power of oligarchs is rarely permanent. And as several of these cases demonstrate, even the thorough elimination of oligarchs across decades does not preclude their reemergence under conditions that once again favor the accumulation of large fortunes in private hands.

In Indonesia, the impact of material power on the country's ordinary politics is particularly exaggerated for two main reasons: there are few effective limits on the use of money for political and wealth-defense objectives, and countervailing power resources (particularly in civil society) are very weak. The claim is not that oligarchs, who are a relatively new phenomenon in Indonesia, are the only political actors worthy of scholarly attention, that they always win, or that there are not many important political matters about which oligarchs have no strong or common interest (there is no coherent oligarchic position on central control versus regional autonomy, for instance). Rather, it is that the power of oligarchs is formidable and that their influence over the country's politics is deep and distorting. Ironically, because of the myriad ways available for oligarchs to express their power within Indonesia's democracy, their role is arguably greater since Suharto's fall than before the transition. To the dismay of progressive Indonesians and their allies abroad, the wealth power of oligarchs shapes and constrains Indonesia's democracy far more than democracy constrains the power of wealth. There is nothing necessarily permanent about this oligarchic dominance. But for the present, oligarchs and oligarchy rightfully hold a central place in the analysis of Indonesian politics. 


\section{Power Resource Theory and Oligarchs}

A focus on oligarchs and oligarchy is rooted in power resource theory. As articulated by Korpi, this theory starts with the distribution of power capacities across members of a political community. It argues that "we should reverse the behavioral approach and begin the study of power with power resources rather than with the exercise of power." ${ }^{3}$ Differences in power resources, especially when they are large, affect what various actors or groups in a society can do, including what they might threaten, or merely be reasonably anticipated, to do. The forms of power that matterhow they are blended, who has power and on what scale, and how power distributions are shifting-are all difficult to assess. Contending actors must constantly evaluate their own power resources and those of others, and act accordingly.

Power resource theory recognizes that influence and leverage can be difficult to measure, and that power held is not always power used. I might possess tremendous power capacities and yet never display them because others whose interests conflict with mine already understand what I am capable of and allow me to prevail without provoking me to act. This outcome constitutes a very real manifestation of power, however silent or invisible its expression. I can also free-ride as others with similar interests fight the political battles and achieve the desired outcomes for me. Or I might benefit from prior political victories that produced policies, norms, or institutions that structurally satisfy my core political goals (at least for the present). In such circumstances, political inaction leaves no trace evidence or data points hinting at the immensity of my power or revealing how my vital political interests are being satisfied.

With its emphasis on capacities, power resource theory posits that at any given time every member of society possesses some quantum of power, ranging from very small (almost zero) to immense. If we could estimate the power capacities of each person, we could rank members of society from least to most powerful. A nonexhaustive list of key power resources includes formal political rights, official positions (both inside and outside government), coercive power, mobilizational power, and material power. ${ }^{4}$ The first four of these, when distributed in highly exclusive or concentrated ways, are the basis of what is generally known as "elite" politics. The last one, material power, is the basis of oligarchy. All five of these power resources exist in Indonesia, and each plays a role in the country's politics. For instance, formal political rights, which range from citizenship to the opportunity for all adults to participate politically and vote in the country's various democratic contests, are important not only on election day, but also prior to elections via the polling-posturing-positioning game that takes place among parties and top political contenders (both of which are heavily populated by oligarchs). Official positions, whether as government officials or as leaders of major organizations such as parties, corporations, unions, religious organizations, and even huge soccer clubs, are an enormous power resource for the individuals who hold them because these persons can exercise the rule-based

\footnotetext{
${ }^{3}$ Walter Korpi, "Developments in the Theory of Power and Exchange," Sociological Theory 3,2 (1985): 33. For a sophisticated discussion of power resource theory and a critique of competing approaches (including pluralism), see Evelyne Huber and John D. Stephens, Democracy and the Left: Social Policy and Inequality in Latin America (Chicago, IL: University of Chicago Press, 2012), pp. 35-40.

${ }^{4}$ Jeffrey A. Winters, Oligarchy (Cambridge: Cambridge University Press, 2011), pp. 11-20.
} 
prerogatives of the entities they oversee and, by virtue of office, deploy its resources and personnel (which can include police, soldiers, and security staff). Coercive power resources refer to non-official capacities to unleash violence. A general in a country's armed forces is empowered by official position; a warlord or mafia figure is empowered by access to means of coercion and by personal command over armed followers or underlings.

Mobilizational power refers both to the capacity of some elites to move others in politically formidable ways (as Sukarno did before becoming president, or as Gandhi or Martin Luther King, Jr. did as activists) and to the power-augmenting status of being mobilized. Hundreds of thousands (or millions) of people who are otherwise minimally empowered can, in concert, become tremendously powerful when they are organized into a union or perhaps mobilized for mass actions that disrupt the politics of the ordinary (often short-circuiting or overwhelming oligarchic power in the process). Except when well institutionalized, most manifestations of mobilizational power are episodic and very difficult to sustain due to the great personal demands mobilization places on participants. ${ }^{5}$

Material power, the last category, is the basis of oligarchic power. Oligarchs are actors empowered by wealth-a power resource that stands out among the other forms. It is by far the most versatile in that it is easily converted into other manifestations of power. This can range from buying offices and political-legal outcomes to hiring masses and armed militia. Wealth is unique in that it can be deployed through others for its own defense, while making few direct personal demands on oligarchs themselves. Unlike workers or demonstrators, oligarchs can sleep, play, or be far away while their wealth power is fully engaged around the clock and for decades if necessary. It is oligarchic resources that get exhausted, not oligarchs.

Throughout history, extreme concentrations of wealth have faced constant political and social challenges. Great fortunes in the hands of a few attract threats from various directions-from the non-rich, from states or powerful rulers above, or laterally from other oligarchs. The unique political challenge for oligarchs, and the basis of oligarchy, is defending against these threats. ${ }^{6}$

Oligarchy does not refer to a system of rule by a particular set of actors. It describes the political processes and arrangements associated with a small number of wealthy individuals who are not only uniquely empowered by their material resources, but set apart in a manner that necessarily places them in conflict with large segments of the community (often including each other). Oligarchy centers on the political challenges of defending concentrated wealth. The oligarchies that have existed since the dawn of settled human history and

\footnotetext{
${ }^{5}$ Ideology is not a power resource in its own right that can be "held" or possessed by an individual actor. Rather, ideologies are contested and constructed ideas developed by multiple actors over time. They reflect the relative strength of other power resources-with the greatest contest since the mid-nineteenth century being between those wielding material power and the mobilizational power of workers. For a careful treatment of this contest, see Dietrich Rueschemeyer, Evelyne Huber Stephens, and John D. Stephens, Capitalist Development and Democracy (Chicago, IL: University of Chicago Press, 1992).

${ }^{6}$ This political activity by individual oligarchs has the salutary effect of defending material stratification itself, whether or not oligarchs think systemically or collude for this purpose.
} 
that continue to exist today differ according to how those political challenges have been met. $^{7}$

In other words, oligarchy is defined by the politics of wealth defense, and it assumes different forms as the threats to and responses by oligarchs change. Oligarchs can stand alone and rule, or they can be embedded within authoritarian regimes and democracies. Important variations in oligarchy depend on whether oligarchs are armed or disarmed and, by extension, whether they are involved in the violence at the root of all exclusive claims and rights to property. It also matters whether oligarchs are directly engaged in rule, and, if so, whether they rule as individuals or as a group. Combinations of these factors result in four types of oligarchy: warring, ruling, sultanistic, and civil. ${ }^{8}$ During Dutch rule there were no Indonesian oligarchs to speak of. The country evolved into a classic example of sultanistic oligarchy under Suharto. Since 1998, it has become an electoral ruling oligarchy, fusing strong elements of democracy and ruling oligarchy, but without effective institutions of law to guarantee the impersonal defense of property and wealth.

Oligarchs are distinct from elites, who exert their minority influence based on nonmaterial power resources (the first four types elaborated above). The categories of oligarch and elite can be layered upon each other, with oligarchic power potentially leading to elite power (and vice versa). But there is no necessary overlap. Many oligarchs have only material power resources at their disposal, and many elites never amass empowering fortunes. It is also important to recognize that democracy and oligarchy are not necessarily zero-sum political phenomena, as the Indonesian case clearly shows. Oligarchs are the political product of extreme material stratification in society rather than the result of a democratic deficit. It follows that democratic transitions have no automatic effect on the power resources available to oligarchs, and thus on oligarchy.

Democracy and oligarchy are defined by distributions of radically different kinds of power. Democracy refers to dispersed formal political power based on rights, procedures, and levels of popular participation. By contrast, oligarchy is defined by concentrated material power based on enforced claims or rights to property or wealth. The nature of the political powers that get widened or narrowed as systems become more or less democratic is distinct from the political powers that can be dispersed or concentrated materially. This is why democracy and oligarchy are remarkably compatible provided the two realms of power do not clash. $^{9}$

Oligarchs are aware that democracy poses potential new threats, and the historical record dating back to Aristotle is filled with nervous commentary from the wealthy on how democratic power in the hands of the many could challenge stratification by taking and redistributing the wealth of the few. But such clashes have been infrequent-both because oligarchs are always present and vigilant at moments of democratic founding (thus ensuring that various wealth-defending safeguards are

\footnotetext{
${ }^{7}$ Winters, Oligarchy, p. 39.

${ }^{8}$ For a further elaboration and theorization of these types of oligarchies, see ibid., chapter 1, and passim.

${ }^{9}$ Ibid., p. 11.
} 
built into the institutions, laws, and practices of participatory polities, as James Madison and his colleagues did in the US case), and because the formidable capacities of oligarchs to punish hyper-performing democracies are well known and tested at one's peril.

Indonesia after the fall of Suharto represents a complex but stable blend of oligarchy and democracy, with wealth-power pervading a political arrangement that tolerates and responds to popular participation. The country's political system evolved rapidly into an electoral ruling oligarchy in which holding office is increasingly linked to private wealth. ${ }^{10}$ Indonesia is, moreover, an important example of what might be termed democracy without law. Some oligarchs are directly engaged in rule as they operate within party institutions and compete for office according to basic democratic norms. At the same time, they and others outside the ruling group engage in an obligatory process of wealth transfers among each other (bagi-bagi) as oligarchs and elites compete over who gets to keep the riches from the archipelago's natural and agricultural resources. Having rules and norms in the democratic political realm does not ensure oligarchs are tamed by impersonal institutions of law. Quite the contrary: law in Indonesia routinely bends to oligarchs and elites, even as it applies in a mundane (if technically flawed) manner to the vast majority of the population. Thus, Indonesia is not a lawless society. Rather, its "rule of law" problems are primarily due to the inability of the legal system to tame the ultra-powerful.

Given that oligarchy can be readily blended with democracy and other political forms, it means that oligarchic theory neither denies nor conflicts with other approaches that examine the role of actors or groups in civil society struggling to shape policy or win key political battles. There are issues about which there is no coherent oligarchic stance or interest, and there are also matters about which oligarchs care deeply and yet clash spectacularly among themselves. Meanwhile, social organization and movements from below can fluctuate significantly over time, and people-power moments can burst onto the political stage with very little warning. An acknowledgement of tremendous oligarchic power does not imply that other power resources, particularly mobilizational power and popular participation, are irrelevant. The challenge is to understand when, how, and how long they become dominant and decisive (as they briefly did in 1998).

This article traces how oligarchs incubated during Suharto's New Order quickly came to dominate Indonesia's new democracy as the regime collapsed and how their control has deepened since $1998 .{ }^{11}$ The central argument is that from a power resource perspective, oligarchs are disproportionately influential actors within Indonesia's political economy, that they arose and gained power during Suharto's New Order, and that the transition to democracy does not constitute a significant disruption or even diminution of their power. Oligarchy itself changed dramatically with Suharto's fall-

\footnotetext{
${ }^{10}$ The wealth is already owned prior to gaining office or is quickly amassed after supporting oligarchs deploy their resources to elevate individuals to elite positions (which the newly elevated almost always use to grab enough wealth to reduce their reliance on oligarchs by becoming one themselves).

${ }^{11}$ In addition to Winters, Oligarchy, see also Richard Robison, Indonesia: The Rise of Capital (Sheffield: Equinox Publishing, 1986); Jeffrey A. Winters, Pozver in Motion: Capital Mobility and the Indonesian State (Ithaca, NY: Cornell University Press, 1996); and Richard Robison and Vedi Hadiz, Reorganising Power in Indonesia: The Politics of Oligarchy in an Age of Markets (London: Routledge Curzon, 2004).
} 
shifting from the sultanistic to the ruling form-with important consequences for how wealth defense is attempted and secured in Indonesia. But oligarchy did not disappear. The emphasis in this piece is on how oligarchic power is manifested in contemporary Indonesia. Although oligarchs and oligarchy are not the sole focus of the country's politics, they constitute its most important element as long as ordinary citizens remain poorly organized and minimally empowered.

\section{Emergence of Oligarchs in Indonesia}

The oligarchic capture of Indonesian democracy began with a group of oligarchs who played a background role in Suharto's collapse and experienced virtually no disruptions in their ranks during the years of political transformation. But accompanying the transition from dictatorship to democracy was an equally important transition: from a sultanistic oligarchy under which the ultra-rich were tamed personally by Suharto, to a more chaotic electoral ruling oligarchy under which there are far fewer effective constraints on oligarchic power. The capacity to use wealth strategically has emerged as one of the most vital power resources in Indonesian electoral politics.

Unlike in the Philippines, where landed oligarchs took root during the nineteenth century under the Spanish, the Dutch East Indies had only elites and no oligarchs during the colonial period. Despite government programs designed to foster entrepreneurs, the Sukarno years from World War II through the late 1960s were far too chaotic economically and politically for a group of Indonesians empowered by concentrated wealth to emerge. It was during the sultanistic rule of Suharto that Indonesia's modern oligarchs first arose. He not only created the country's oligarchs practically out of nothing, but he controlled them like a mafia Godfather. No matter how big or rich you became, Suharto could break you. All issues of wealth defense, property claims, and contracts radiated out from the Don. This put a premium on the politics of proximity-being close to Suharto mattered more than anything else. The more that was at stake financially, the more vital it was to have access to the inner circles around the dictator, if not to the man himself.

Suharto began as a member of the Indonesian elite holding the formal office of general in the armed forces. But he quickly became ultra-wealthy and thus became an oligarch himself-ruling a sultanistic oligarchy as first among equals. A key element in operating such a sultanistic oligarchy is that all competing bases of independent power must be subverted. Suharto and his cronies made sure this was the case across the entire economy and bureaucracy. We know from the work of Daniel Lev that it was not Suharto who first attacked Indonesia's legal system. ${ }^{12}$ Lev reminds us that the relatively strong and independent legal infrastructure that existed in the early 1950s was attacked first by General Nasution and President Sukarno. Suharto finished the job and made sure that the only recourse oligarchs had, and the only thing that could reliably tame them, was the dictator himself. His most significant contribution to

${ }^{12}$ See Daniel S. Lev, "Colonial Law and the Genesis of the Indonesian State," Indonesia 40 (October 1985): 57-74; Daniel S. Lev, Legal Evolution and Political Authority in Indonesia: Selected Essays (The Hague: Kluwer Law International, 2000); and Daniel S. Lev, "The State and Law Reform in Indonesia," in Law Reform in Developing and Transitional States, ed. Tim Lindsey (New York, NY: Routledge, 2007). 
Indonesia's crippled system of law after 1965 was to make sure it could not recover from the devastating blows it sustained during Sukarno's Guided Democracy period.

Indonesia's new stratum of oligarchs was built up in phases and driven initially by General Suharto's efforts to consolidate his regime once Sukarno was pushed aside. Suharto focused first on extracting national wealth that could be channeled to buy off potential competitors in the armed forces. He encouraged early business partnerships between ethnic Chinese Indonesians and the generals. By the mid-1970s, erstwhile Chinese traders emerged as oligarchs in their own right. It was in the early 1980s that Suharto paid more attention to pribumi Indonesians through instruments like "Team $10 .{ }^{\prime 13}$ Later in that same decade, Suharto's children arose as the last significant group of oligarchs. Indeed, one of the most important factors that weakened Suharto's New Order was his grown children's capacity to disrupt the system of wealth defense and oligarchic taming based on the politics of proximity to the dictator. Suharto's children, whose access to their father trumped all other channels of security for oligarchs, rapidly became the most predatory and disruptive force within Indonesia's oligarchy. Suharto refused to limit or punish his children, and thus for other oligarchs it was no longer possible to turn to him to safeguard property, enforce business deals, limit predations, and manage risks (most of which were increasingly coming from the kids themselves). The New Order went from being a highly predictable and reasonably tamed oligarchy, which tends to promote investment, to being a frustrating and increasingly risky system for oligarchs to navigate within. Not only did Suharto's children engage in predatory behaviors that threatened domestic and foreign oligarchs and weakened the economy, but a broader cohort of predatory actors linked to the children grabbed a piece of the action as well.

Once it became clear that powerful figures like General Benny Murdani and even General Prabowo Subianto could pay a high price with Suharto for speaking up about the friction his children were causing, Indonesia's oligarchs knew that the reliable system of security and response based on proximity to Cendana, Suharto's private residence, had broken down. Cendana was increasingly the source of wealth threats rather than the epicenter of wealth defense. The final straw came when Suharto started grooming some of his children for political succession. This ominous development occurred in the years just prior to the onset of the financial crisis in 1997. It is not that Indonesia's elites and oligarchs (and equally frustrated foreign counterparts in places like Washington, DC, and New York) worked and plotted to bring Suharto down. Rather, they quietly but actively abandoned him as he faced what would be the final economic shock of his reign. It was readily apparent to everyone, not least the students beginning to assemble in the streets, that Suharto was exposed and politically vulnerable.

When the dust finally settled, and democracy took shape, all of the oligarchs and elites were still there. Virtually none went down with Suharto except one or two who stood by him to the end. Although oligarchic and elite continuity was nearly 100 percent, two things had changed. One was that the actors at the top had to adapt to the new democratic game. Not only did they do this with relative ease, but they were better positioned than anyone else to capture and dominate Indonesia's money-driven

\footnotetext{
${ }^{13}$ For an extensive discussion of Team 10 (Tim Keppres 10), see Winters, Power in Motion, chapters 3-4.
} 
electoral politics. Whereas many oligarchs in the Philippines and some Latin American democracies are armed and can engage their militias against each other, for historical reasons Indonesia's oligarchs were disarmed from the start. This has facilitated the game of divvying up the democratic spoils among them and helped keep the competition fairly orderly. The oligarchs have the money, media empires, networks, and positions in the parties (or the resources to create new ones) that allow them to dominate the new democratic system and pursue strategies of wealth defense outside the political theater. To contend for office (or, for the ethnic Chinese, to fund indigenous Indonesians who run), oligarchs have to deploy huge sums of money, sometimes down to the village level.

The other thing that changed when the New Order ended, however, is that Indonesia went practically overnight from having Suharto to constrain oligarchs to having to rely on the country's debilitated legal infrastructure to do the job. Unfortunately for the nation, there are no longer any strong, independent, or impersonal institutions of law and enforcement to which Indonesia's most powerful actors must submit. On matters of property, wealth, economy, corruption, and criminality of all kinds, the law bends to individual oligarchs and elites rather than the reverse. This is because these actors have the material power resources at their disposal to buy and distort the legal system, from the police and prosecutors up to the judges and politicians. The multiple pathologies this creates in Indonesia have undercut the momentum of Reformasi and spawned dangerous longings for the predictability of an iron-fisted leader.

There has been a steady, but misplaced, undercurrent of dissatisfaction with Indonesia's democracy. Rampant corruption, elected officials who perform wretchedly, indecisive leadership, a surge in fundamentalist and sometimes violent Islamic politics, ${ }^{14}$ and slower economic growth rates have been blamed on Indonesia's democratic transition after 1998. It is not uncommon to hear people at all levels of society express nostalgia for the order of Suharto's regime. Lt. Gen. (ret.) Kiki Syahnakri, the vice-chair of Indonesia's vocal Association of Retired Officers, opined that "from a social and cultural perspective, Indonesia is just too unwieldy for the extreme liberal democracy we've adopted." ${ }^{15}$ When pressed on the point that Indonesians have conducted themselves nonviolently and responsibly during the many national and local elections held since 1998, and that the worst distortions of the system have been at the hands of oligarchs, Syahnakri insisted the blame rests with average citizens. "The problem is not that the people are violent, it is that they are illprepared for the choices they are making in elections and end up letting themselves be more influenced by money than anything else." ${ }^{16}$

Even some academics have added their voices to the democratic critique. After reviewing the higher growth rates achieved during the Suharto dictatorship and lamenting Indonesia's weaker economic performance since the transition to

14 "In Religion's Name: Abuses against Religious Minorities in Indonesia," Human Rights Watch, February 2013, at http: / / www.hrw.org/sites/default/ files/reports / indonesia0213_ForUpload_0.pdf, accessed July $31,2013$.

${ }^{15}$ Interview with the author, Jakarta, May 12, 2012.

${ }^{16}$ Ibid. 
democracy, Duncan and McLeod write: "According to Sir Winston Churchill: 'It has been said that democracy is the worst form of government, except all those other forms that have been tried from time to time.' The post-Soeharto decline in Indonesia's economic performance calls this view into question. ${ }^{\prime 17}$ In fact, it is misguided to suggest that democracy is to blame for slower growth rates since the inception of Reformasi. If anything, Indonesia's democracy works remarkably well considering the political damage inflicted on the body politic for a decade by Sukarno and then for three decades by Suharto. An alternative explanation is that it was Indonesia's other transition in 1998, from a tamed to an untamed oligarchy, that caused risks and costs to rise for those controlling capital, resulting in more uncertainty, higher costs for reliable wealth defense, and lower rates of investment. Indonesia's overarching "problem" is that the country is burdened by a group of powerful oligarchs and elites whose pathological behaviors are barely constrained. And, regrettably, electoral democracy is poorly designed to tame them. Indeed, Indonesia's oligarchs and elites have actually captured and now thoroughly dominate the country's democratic institutions, and yet do not appear capable of using them collectively to achieve a civil oligarchy with a strong legal infrastructure that would defend property rights in exchange for oligarchs themselves submitting to the rule of law.

\section{Oligarchic Scale, Intensity, and Material Power Index}

One of the most dramatic transformations in Indonesia's political economy since the end of World War II, but especially after the collapse of Sukarno's Old Order, is the rise of extreme material stratification. As the data presented at the outset showed, this development produced a crop of fabulously wealthy and powerful actors at the apex of the system. Indeed, wealth in Indonesia today is probably more concentrated in the hands of a few oligarchs than it has been for most of the archipelago's recorded history. Table 1 presents comparative data on the forty richest Indonesians. The data focus on oligarchic scale, intensity, and their Material Power Index (MPI). These indicators provide insights into the proportion of the country's total material endowments concentrated in the hands of a tiny segment of the population, as well as the relative material power of oligarchs compared to that of the average Indonesian.

With an average net worth of US $\$ 2.13$ billion, the oligarchic scale of the forty richest Indonesians is substantially larger than that of their counterparts in Southeast Asia. Indonesia's top billionaires are, on average, over 50 percent richer than those in Singapore, own wealth at roughly double the scale of those in Thailand, and have accumulated fortunes more than 250 percent larger than those of Filipino oligarchs.

\footnotetext{
${ }^{17}$ My emphasis. Duncan and McLeod $(2007,75)$ press on: "Can we actually say that the institutional changes that constitute Indonesia's recent democratisation are generally for the better? To put it more bluntly: was democratisation the right approach? Or was it a mistake to impose such a system on Indonesia at this stage of its development, simply because it has been highly successful in the West? Certainly, the changes allow wide participation in politics by citizens and their organisations, but what about the impact on economic performance? As noted at the outset, the record does not look good so far, eight years down the track. Will matters eventually improve of their own accord? Not necessarily." Ron Duncan and Ross H. Mcleod, "The State and the Market in Democratic Indonesia," in Indonesia: Democracy and the Promise of Good Governance, ed. Ross H. McLeod and Andrew MacIntyre (Singapore: Institute of Southeast Asian Studies, 2007), pp. 73-92.
} 
Robert and Michael Hartono, who own the Djarum empire valued at US\$14 billion (an increase of US $\$ 3$ billion in one year), control the single largest fortune in Southeast Asia. A different pattern is evident for the measure of oligarchic intensity (the weight of the upper oligarchs' wealth-power in the overall economy). The combined fortunes of the top forty oligarchs in Indonesia equal 10 percent of GDP. This figure is modest, however, compared to 20.4 percent in Singapore and 26 percent in Malaysia.

Table 1. Wealth of Top Forty Oligarchs

Oligarchic Scale, Intensity, and Material Power Index in Selected Countries, 2011

\begin{tabular}{|c|c|c|c|c|c|c|c|c|c|c|}
\hline & $\stackrel{\overparen{\Xi}}{\Xi}$ & 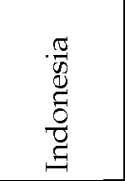 & $\begin{array}{l}\frac{d}{d} \\
\frac{1}{2} \\
\frac{2}{2} \\
\frac{Z}{2} \\
\frac{1}{1}\end{array}$ & 岕 & $\frac{\text { D }}{\stackrel{\mathbb{J}}{\mathbb{J}}}$ & $\frac{\sqrt[\pi]{\frac{\pi}{0}}}{\sum_{i}^{\frac{\pi}{2}}}$ & 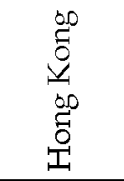 & 营 & 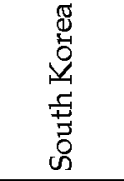 & 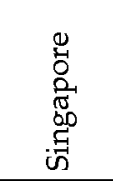 \\
\hline $\begin{array}{l}\text { Oligarchic } \\
\text { Scale (bln) }\end{array}$ & $\$ 3.78$ & $\$ 2.13$ & $\$ 0.85$ & $\$ 16.66$ & $\$ 1.14$ & $\$ 1.61$ & $\$ 3.78$ & $\$ 2.32$ & $\$ 1.64$ & $\$ 1.36$ \\
\hline \begin{tabular}{|l|}
$\begin{array}{l}\text { Total of } 40 \\
\text { (bln) }\end{array}$ \\
\end{tabular} & $\$ 151$ & $\$ 85$ & $\$ 34$ & $\$ 667$ & $\$ 45$ & $\$ 64$ & $\$ 151$ & $\$ 93$ & $\$ 66$ & $\$ 54$ \\
\hline \begin{tabular}{|l|} 
Rank 1 \\
(bln)
\end{tabular} & $\$ 9.30$ & $\$ 14.00$ & $\$ 7.20$ & $\$ 59.00$ & $\$ 7.40$ & $\$ 12.40$ & $\$ 22.00$ & $\$ 8.80$ & $\$ 9.30$ & $\$ 8.90$ \\
\hline $\begin{array}{l}\begin{array}{l}\text { Rank } 40 \\
\text { (bln) }\end{array} \\
\end{array}$ & $\$ 1.86$ & $\$ 0.63$ & $\$ 0.09$ & $\$ 7.00$ & $\$ 0.20$ & $\$ 0.16$ & $\$ 0.95$ & $\$ 0.93$ & $\$ 0.53$ & $\$ 0.21$ \\
\hline $\begin{array}{l}\text { GDP/ } \\
\text { capita }\end{array}$ & $\$ 5,203$ & $\$ 3,361$ & $\$ 2,082$ & $\$ 47,992$ & $\$ 5,151$ & $\$ 8,479$ & $\$ 33,667$ & $\$ 21,844$ & $\$ 23,804$ & $\$ 49,352$ \\
\hline $\begin{array}{l}\text { Oligarchic } \\
\text { Intensity }\end{array}$ & 2.2 & 10.2 & 15.7 & 4.4 & 13.1 & 26.0 & 62.3 & 18.4 & 5.7 & 20.4 \\
\hline $\begin{array}{l}\text { Material } \\
\text { Power } \\
\text { Index }\end{array}$ & 726,504 & 632,740 & 408,261 & 347,141 & 221,316 & 189,881 & 112,276 & 106,207 & 68,896 & 27,557 \\
\hline
\end{tabular}

Notes: Data on forty richest oligarchs is from Forbes "40 Richest," 2011, www.forbes.com. Data on GDP and GDP/capita are from the CIA Factbook. Oligarchic scale (row 1) is the average wealth of the top 40 oligarchs (in US\$ billions). Oligarchic intensity (row 6) is the total wealth of the top 40 oligarchs (row 2) as a percent of GDP. The Material Power Index (row 7) is the average wealth of the top 40 oligarchs (row 1) divided by GDP/capita (row 5). The MPI is a measure also presented in Jeffrey A. Winters and Benjamin I. Page, "Oligarchy in the United States?" Perspectives on Politics 7,4 (December 2009): 731-53; and Winters, Oligarchy, although in those studies median income was used instead of GDP/capita. Calculations by the author.

The most telling figures are contained in the Material Power Index, which measures the gap in material resources separating oligarchs from average citizens in their societies. Although there were rich and poor Indonesians at independence in 1945, the distribution of wealth was relatively egalitarian by twenty-first century standards. The MPI separating political leaders from common Indonesians was a multiple in the hundreds, while the MPI separating the richest traders from the median citizen was at most a multiple in the low thousands. ${ }^{18}$ In 2010, the MPI of the richest Indonesians was over 630,000 to 1 . This extreme stratification in Indonesia is 50 percent higher than in the Philippines, more than twice that seen in Thailand, over three times

${ }^{18}$ Amry Vandenbosch, "A Problem in Java: The Chinese in the Dutch East Indies," Pacific Affairs 3,11 (1930): 1001-17. See also M. C. Ricklefs, A History of Modern Indonesia Since c. 1200 (Stanford, CA: Stanford University Press, 2008). 
the gap in Malaysia, and more than twenty times the gap between the fortunes of the very rich and the rest in Singapore.

Although individual wealth is a key power resource across all polities and throughout history, the political potency of that wealth varies significantly. Policy changes, legal regimes, institutional arrangements, and countervailing power resources such as coercion and mass mobilization can amplify or diminish the impact of wealthpower (though rarely neutralize it completely or permanently). Weaknesses in Indonesian civil society, the rapid dispersion of popular forces after Suharto's fall, and the institutional capture of Indonesian politics by oligarchs (especially via political parties and the media) has allowed the power of wealth to expand with each new round of electoral contestation.

This is not to say that Indonesia's democracy is a sham. On the contrary, by the procedural standards of Schumpeter's "free competition for a free vote" and Dahl's criteria of "contestation and inclusiveness," ${ }^{19}$ Indonesia performs reasonably well. It is true that candidates sometimes unleash dirty tricks against each other, that there have been irregularities with voter lists, and the biggest portion of campaign finance is off the books (an important point revisited below). And yet, the country has held three national elections since 1999, on time, every five years. It has also held hundreds of regional elections on a regular basis. Unlike in the Philippines, where election-related fatalities are high and candidates are assassinated, democracy in Indonesia is passionate but generally peaceful. Candidates follow most electoral rules, parties take turns campaigning according to the published schedules, voters cast their ballots in secret, and losing candidates overwhelmingly step down without resistance. There is freedom of assembly, expression, and the press. Although there is little ideology involved, and party platforms are fairly meaningless, various matters get raucously debated as parties and candidates try to shape the discourse. Most importantly, the winners are not known in advance. There have been surprising and sometimes spectacular wins and losses.

All of this political activity unfolds in a context of a poorly organized civil society, which augments the influence of oligarchs. In one sense, civil society in Indonesia is active and robust. Reflecting the country's liberal freedoms, there is a proliferation of organizations, causes, seminars, workshops, and publications. This political engagement can sometimes deliver defeats to oligarchs and elites. But for reasons of history and culture, civil society in Indonesia is also badly fragmented, poorly mobilized, and provides an ineffective counterbalance to the captive grip oligarchs have on how democracy functions. As in other democracies where the power of wealth is deployed with few limitations, oligarchs play a central role in shaping who can contend for office or get appointed to top political posts. The result is that Indonesians get to choose among options that are strongly oligarchically determined.

\footnotetext{
${ }^{19}$ See Joseph A. Schumpeter, Capitalism, Socialism and Democracy, 3rd edition (New York, NY: Harper Perennial, [1942] 2008), chapter 22; and Robert A. Dahl, Polyarchy: Participation and Opposition (New Haven, CT: Yale University Press, 1972).
} 


\section{Oligarchs Fund Jokowi}

The election of Jakarta governor Joko Widodo (Jokowi) in 2012 provides a useful illustration of the role oligarchic intervention plays in the democratic choices available to Indonesians. Jokowi challenged and defeated the incumbent Jakarta governor, Fauzi Bowo, a classic oligarchic apparatchik. Part of Jokowi's strategy was to pretend he did not have a strategy. Instead, he adopted an "aw shucks" public posture of relaxed simplicity, made a lot of jokes, and spent much of his time visiting ordinary people and the poor across the capital. The intended message was that, as an outsider from the city of Surakarta, he was untainted by the notorious "money politics" game that infuses most Indonesian political contests. As a candidate, he presented very few concrete plans for solving Jakarta's chronic problems and never explained how he would confront the capital's powerful and deeply entrenched interests.

His efforts to distance himself from the fact that his candidacy was possible only because he had major oligarchic backers reached comical proportions during the campaign. The following exchange unfolded on live television in July 2012, soon after Jokowi outpaced Fauzi in the first round of voting:

Karni (TVOne host): Bagaimana dengan adanya tuduhan sekarang ini bahwa ternyata timnya Pak Jokowi melakukan money politics? [What about accusations lately that it turns out your team has engaged in money politics?]

Jokowi: [Laughs] Money politics duitnya dari mana, Pak Karni? Untuk kampanye saja saya harus jualan baju ... Lihat spanduk saya paling sedikit. Money politics di mana? Duitnya dari mana? [Money politics, money from where, Mr. Karni? Just to campaign I have to sell T-shirts. Notice I've got the fewest banners. Where is the money politics? Money from where?]

Karni: Habiskan berapa kalau kampanye kemarin? [How much did you spend on your recent campaign?]

Jokowi: Kurang-lebih antara ... [stuttering] ... lima-belasan. [More or less around ... fifteenish.]

Karni: [Incredulous] Lima-belasan ... milyard!? [Fifteenish ... billion [rupiah]!?] [which is about US\$1.5 million]

Jokowi: Ya ... itupun hampir 90 percent itu dari sumbangan. [Yeah ... and even that was almost 90 percent from donations.] [The candidate then mentions a list of ordinary folk, friends, and family who donated.]

Karni: Lima-belas milyard itu hampir tidak masuk akal untuk [kampanye] gubernur Jakarta, Pak, karena bupati saja di Jawa sekarang paling kurang limapuluh [milyard], Pak. ${ }^{20}$ [Fifteen billion makes almost no sense in a campaign for governor of Jakarta, sir, because even running for regent in Java now costs at least fifty, sir.]

20 "Jokowi vs Fauzi Bowo di Indonesian Lawyers Club (ILC) 1..." Video clip, YouTube, July 17, 2012. http: / / www.youtube.com/ watch?v=mzjl1vkWuwo, accessed July 31, 2013.. This forum, hosted by Karni Ilyas, was televised live by TVOne from the Indonesia Lawyers' Club in Jakarta. Guests interviewed via satellite included Joko Widodo and Governor Fauzi Bowo. 
Days later, Tempo magazine published a revealing article focusing on the oligarchs backing Jokowi's candidacy. ${ }^{21}$ The key enablers were tycoon Hashim Djojohadikusumo and his brother Gen (ret.) Prabowo Subianto, who will contest the presidency in 2014 as the candidate of the Gerindra party, which Hashim also heavily subsidizes. At the last minute, a supportive role was also played by former president and PDI-P (Partai Demokrasi Indonesia-Perjuangan, Indonesian Democratic Party-Struggle) head Megawati Sukarnoputri (against the designs of her husband, Taufik Kiemas). ${ }^{22}$

Despite Jokowi being a recently elected PDI-P mayor of a medium-size city, it was Gerindra that set his candidacy in motion. Muhammad Taufik, chairman of Gerindra Jakarta, noted that communications with Jokowi intensified toward the end of 2011. Prabowo met him in February of 2012 following an invitation arranged by Hashim, who had known Jokowi for several years. Within weeks the candidate had an audience with Hashim himself. It was at this meeting that Jokowi was asked by Hashim to enter the Jakarta gubernatorial contest. Funding commitments were also made. ${ }^{23}$ Meanwhile, Prabowo met with a reluctant Megawati to urge her to back her own party's candidate. If she did not agree, he was ready to cobble together an alliance of smaller parties to back the plan. It was Hashim and Prabowo who selected Jokowi's running mate (Basuki Tjahaja Purnama, nicknamed "Ahok") and announced to the press the duet's intention to run. Prabowo told the reporters he was even willing to serve as chairman of the campaign team.

In early March 2012, the PDI-P had invited Jokowi to Jakarta to subject him to a five-minute "fit and proper" test, and to explore his readiness to seek Jakarta's top office. He informed Megawati that he was willing, but that despite the fact that he was a minor millionaire, the obvious obstacle was money. With a personal net worth of only US $\$ 3$ to US $\$ 5$ million, ${ }^{24}$ he lacked the funds to mount an effective Jakarta-scale campaign against the well-heeled incumbent. Only oligarchs had the power resources to convert Jokowi's potential as a candidate into a reality. In the event, Prabowo had already signaled to Jokowi via Ahok that the necessary resources would be provided. Tempo reports:

Prabowo first met Ahok around [the] end of February [2012] at the Intercontinental Hotel in Jakarta. Ahok said, "I don't have money," and Prabowo responded, "I'm not asking for your money. We will bear all the expenses."

\footnotetext{
${ }^{21}$ This section draws on Widiarsi Agustina et. al., "Who Owns Jokowi?" Tempo, July 242012 , http: / / asiaviews.org/ index.php?option=com_content\&view=article\&id=38312: who-owns-jokowi\&catid =1: headlines\&Itemid=22, accessed July 31, 2013; and Widiarsi Agustina et. al., "Jokowi Tak Mau Didikte Prabowo dan Mega," Tempo, July 23, 2012, http: / / www.tempo.co/ read/news/2012/07/23/078418627/ Jokowi-Tak-Mau-Didikte-Partai-Pengusungnya, accessed July 31, 2013.

${ }^{22}$ According to a leading official in one of the smaller parties close to the action, Megawati was offered between US\$2 to US\$3 million in "party assistance" to side with the incumbent in the Jakarta race. After she backed Jokowi, the offer was withdrawn. Confidential interview, January 30, 2013.

${ }^{23}$ Confidential sources indicate that Hashim's outlay for the first round exceeded US\$5 million. Other oligarchs were also tapped for contributions.

${ }^{24}$ The Corruption Eradication Commission's (KPK, Komisi Pemberantasan Korupsi) June 2012 report on Jokowi estimated his assets to be Rp. 28.9 billion. Some estimates of his wealth reach as high as US $\$ 15$ million. Most of his holdings are in the form of property, a factory, and deposits.
} 
Feeling odd, Ahok asked, "Then how do I return the favor? Do you want [the] MRT [mass rapid transportation] project for Pak Hashim?" ${ }^{25}$

Prabowo, Hashim, and Gerindra were vying for something much larger than Jakarta's stalled transit project. They wanted to strengthen their strategic position in the capital while forging closer bonds with Megawati and PDI-P - vital partners in Prabowo's bid for the presidency and for Hashim's wealth defense goals.

The wildly popular Jokowi's victory over the sitting governor was due to a groundswell of support from scores of groups ranging from students to housewives' associations that helped propel him to victory. This important democratic part of the story was made possible, however, by a prior oligarchic move in which the power of wealth placed Jokowi before the voters in the first place. Even if he did come to enjoy grassroots support, he did not arrive at the gubernatorial contest as a consequence of grassroots initiatives or politics.

\section{Media, Oligarchs, and Parties}

Politically ambitious oligarchs also pursue a strategic position in Indonesia's mass media market. Following a short burst of new media voices that emerged after 1998, big money moved aggressively to consolidate most sources of information and communication into roughly a dozen hands. ${ }^{26}$ Table 2 presents a snapshot of the dominant groups. This process accelerated once big political players realized the media could make or break a candidate. A small number of oligarchs now own the vast majority of Indonesia's print, television, radio, and online media outlets. In 1997, on the eve of Suharto's collapse, there were 289 print media outlets. This exploded during the democratic transition to 1,381 in 1999 and 1,881 in 2001. But by 2006 the number had dropped back to 889 .

Major media groups own five out of the six Indonesian newspapers with the highest circulation and all of the four biggest online news media sites. They also own the overwhelming majority of flagship radio networks originating from Jakarta and the largest cities, and a large proportion of local radio stations. The vitally important TV market is dominated by national TV stations that control over 90 percent of viewer hours across the archipelago. Ownership of TV stations is concentrated into five companies that control 96.6 percent of all national stations. ${ }^{27}$ Indonesia's media outlets are free in the sense that muscular intimidation from the state is now rare. But they are also thoroughly corporate and dominated by super-powerful oligarchs.

\footnotetext{
25 "Who Owns Jokowi?" Tempo, July 24, 2012.

${ }^{26}$ Data in this section draw on Nugroho, Yanuar, Dinita Andriana Putri, and Shita Laksmi, "Mapping the Landscape of the Media Industry in Contemporary Indonesia," Report Series: "Engaging Media, Empowering Society: Assessing Media Policy and Governance in Indonesia through the Lens of Citizens' Rights," Jakarta: CIPG and HIVOS, March, 2012, https: / / www.escholar.manchester.ac.uk/api/ datastream?publicationPid=uk-ac-man-scw:168565\&datastreamId=FULL-TEXT.PDF, accessed July 31, 2013.

${ }^{27}$ These are MNC (34.7 percent), TransTV and Trans7 (24.7 percent), Emtek's SCTV and Indosiar (23.9 percent), TVOne and ANTV (10.8 percent), and MetroTV (2.5 percent). The only stations not owned by, or closely linked to, major political figures are SCTV and Indosiar.
} 
Table 2. Oligarchic Dominance of Media in Indonesia, 2011

\begin{tabular}{|c|c|c|c|c|c|c|c|}
\hline & Group & TV & Radio & $\begin{array}{c}\text { Print } \\
\text { Media }\end{array}$ & $\begin{array}{l}\text { Online } \\
\text { Media }\end{array}$ & Other Businesses* & Owner \\
\hline 1 & $\begin{array}{l}\text { Global } \\
\text { Mediacomm } \\
(\mathrm{MNC})\end{array}$ & 20 & 22 & 7 & 1 & $\begin{array}{l}\text { Content production, } \\
\text { Content } \\
\text { distribution, Talent } \\
\text { management }\end{array}$ & $\begin{array}{l}\text { Hary } \\
\text { Tanoesoedibjo }\end{array}$ \\
\hline 2 & $\begin{array}{l}\text { Jawa Pos } \\
\text { Group }\end{array}$ & 20 & $\mathrm{NA}$ & 171 & 1 & $\begin{array}{l}\text { Paper mills, printing } \\
\text { plants, Power plant }\end{array}$ & $\begin{array}{l}\text { Dahlan Iskan } \\
\text { Azrul Ananda }\end{array}$ \\
\hline 3 & $\begin{array}{l}\text { Kelompok } \\
\text { Kompas } \\
\text { Gramedia }\end{array}$ & 10 & 12 & 88 & 2 & $\begin{array}{l}\text { Property, } \\
\text { Manufacturing, } \\
\text { Bookstore chain, } \\
\text { Event organizer, } \\
\text { University }\end{array}$ & Jacob Oetama \\
\hline 4 & $\begin{array}{l}\text { Mahaka } \\
\text { Media } \\
\text { Group }\end{array}$ & 2 & 19 & 5 & NA & $\begin{array}{l}\text { Event organizer, } \\
\text { PR consultant }\end{array}$ & $\begin{array}{l}\text { Abdul Gani, } \\
\text { Erick Thoir }\end{array}$ \\
\hline 5 & $\begin{array}{l}\text { Elang } \\
\text { Mahkopta } \\
\text { Teknologi }\end{array}$ & 3 & $\mathrm{NA}$ & NA & 1 & $\begin{array}{l}\text { Telecommunications } \\
\text { and IT solutions }\end{array}$ & $\begin{array}{l}\text { Sariatmaadja } \\
\text { Family }\end{array}$ \\
\hline 6 & CT Corp & 2 & NA & NA & 1 & $\begin{array}{l}\text { Financial services, } \\
\text { Lifestyle and } \\
\text { Entertainment, } \\
\text { Natural resources, } \\
\text { Property }\end{array}$ & $\begin{array}{l}\text { Chairul } \\
\text { Tanjung }\end{array}$ \\
\hline 7 & $\begin{array}{l}\text { Visi Media } \\
\text { Asia }\end{array}$ & 2 & $\mathrm{NA}$ & NA & 1 & $\begin{array}{l}\text { Natural resources, } \\
\text { Network provider, } \\
\text { Property }\end{array}$ & $\begin{array}{l}\text { Bakrie and } \\
\text { Brothers }\end{array}$ \\
\hline 8 & $\begin{array}{l}\text { Media } \\
\text { Group }\end{array}$ & 1 & NA & 3 & NA & Property (Hotel) & Surya Paloh \\
\hline 9 & MRA Media & NA & 11 & 16 & NA & $\begin{array}{l}\text { Retail, Property, } \\
\text { Food and beverage, } \\
\text { Automotive }\end{array}$ & $\begin{array}{l}\text { Adiguna } \\
\text { Soetowo and } \\
\text { Soetikno } \\
\text { Soedarjo }\end{array}$ \\
\hline 10 & $\begin{array}{l}\text { Femina } \\
\text { Group } \\
\end{array}$ & NA & 2 & 14 & NA & $\begin{array}{l}\text { Talent agency, } \\
\text { Publishing }\end{array}$ & \begin{tabular}{|l|} 
Pia \\
Alisjahbana \\
\end{tabular} \\
\hline 11 & $\begin{array}{l}\text { Tempo Inti } \\
\text { Media }\end{array}$ & 1 & NA & 3 & 1 & $\begin{array}{l}\text { Documentary- } \\
\text { making }\end{array}$ & $\begin{array}{l}\text { Yayasan } \\
\text { Tempo }\end{array}$ \\
\hline 12 & $\begin{array}{l}\text { Beritasatu } \\
\text { Media } \\
\text { Holding }\end{array}$ & 2 & NA & 10 & 1 & $\begin{array}{l}\text { Property, Health } \\
\text { services, Cable TV, } \\
\text { Internet service } \\
\text { provider, University }\end{array}$ & Lippo Group \\
\hline
\end{tabular}

* "Other Businesses" refers to businesses run by the same owner or group owner.

Source: This table is from Nugroho, Yanuar, Dinita Andriana Putri, and Shita Laksmi, "Mapping the Landscape of the Media Industry in Contemporary Indonesia," Table 4.1, p. 39.

The ideological spectrum for the media ranges from conservative to extreme rightwing. Most conflicts and debates among the media arise because of clashes between the oligarchic personalities or political groups that own them. The only other major variation across publications or broadcasts is whether they are stuffy and up-market (like Kompas and MetroTV) or churn out sensationalist, burlesque, or even superstitious fare for the wider market (of which there are too many examples to mention). Serious presidential contenders for the 2014 elections (and major local elections) must buy media access, which in some cases has meant buying television 
and radio stations and newspapers outright. Prabowo and his brother Hashim are in the market to buy TV stations. ${ }^{28}$ Another major oligarch has invested heavily in television and is planning to launch his own national polling outfit in 2013 with the explicit goal of influencing the 2014 presidential contest. $^{29}$

Oligarchic candidates also buy political parties-or buy their way up the party ranks. This happens in several ways. At the regional and local level, candidates pay large sums to party leaders to gain national party support. But the flow also goes downward. Those seeking to be party leaders compete by making enormous payouts to delegates at national party congresses to outflank opponents for posts like party chairperson or secretary general. And in some cases, oligarchs use their money power (or that of their supporters if they are not yet big fish) to create new parties out of nothing. This is what Hashim and Prabowo did with Gerindra, and Surya Paloh did with NasDem. The idea is to make yourself party chair so that you can be catapulted to the presidency. The strategy worked well for President Susilo Bambang Yudhoyono, who was financed by fewer than a dozen oligarchs until he became one himself.

The last phase of buying a party unfolds during the frenzied process of trying to cobble together enough representation in the DPR (Dewan Perwakilan Rakyat, Indonesia's parliament) to meet the threshold to be a presidential contender. In 2009, candidates for the presidency required the support of parties that held at least 20 percent of DPR seats, or which had won 25 percent of the vote. There is always plenty of political horse trading regarding vice-presidential running mates and promises of cabinet posts. But such deals are never enough to make a successful alliance or coalition in Indonesia. A presidential hopeful must also be ready to pay many millions of dollars in cash to his or her party allies. A portion of the payoff flows to the other parties' coffers, and some goes directly into the pockets of party leaders as a political closing fee for being the direct negotiators of the deals. Oligarchic and elite forms of power tend to be mutually supporting within Indonesia's electoral ruling oligarchy. Table 3 summarizes the oligarchic moorings of major political figures within Indonesia's democracy.

\footnotetext{
${ }^{28}$ Nugroho et. al. sum up the concentration and consolidation of Indonesia's media this way: "Today, twelve large media groups control nearly all of Indonesia's media channels, including broadcasting, print media, and online media. They are MNC Group, Kompas Gramedia Group, Elang Mahkota Teknologi, Visi Media Asia, Jawa Pos Group, Mahaka Media, CT Group, Beritasatu Media Holdings, Media Group, MRA Media, Femina Group, and Tempo Inti Media. MNC Group has three free-to-air television channels-the highest number owned by any media group-with twenty local television networks and twenty-two radio networks under its subsidiary, Sindo Radio. Jawa Pos Group has 171 print media companies, including its Radar Group. Kompas, Indonesia's most influential newspaper, has expanded its network to include a content provider by establishing KompasTV, besides the existing twelve radio broadcasters under its subsidiary Sonora Radio Network, and eighty-nine other print media companies. Visi Media Asia has grown into a powerful media group with two terrestrial television channels (ANTV and tvOne) and its quickly growing online media channel vivanews.com. A new media company under Lippo Group, i.e., Berita Satu Media Holding, has already established an Internet-Protocol Television (IPTV) BeritasatuTV, online media channel beritasatu.com, and additionally owns a number of newspapers and magazines. [...] Some important M\&As have taken place recently: Indosiar was acquired by Elang Mahkota Teknologi, a holding company of SCTV; detik.com was bought out by CT Group, the owner of Trans TV and Trans 7; a number of local television channels were taken over by large groups such as MNC Group with its Sindo TV network and Jawa Pos, which has its own TV network. Laws and regulations seem to be toothless in controlling the concentration of the industry as such." See Nugroho, et. al., "Mapping the Landscape," pp. 4-5.

${ }^{29}$ Confidential interview, Jakarta, July 18, 2012.
} 
Table 3. Indonesia's Oligarchic Democracy

\begin{tabular}{|c|c|c|c|c|}
\hline Politician & Oligarch & $\begin{array}{l}\text { Oligarch } \\
\text { Backers }\end{array}$ & Media & $\begin{array}{l}\text { Owns/Bought } \\
\text { Party }\end{array}$ \\
\hline $\begin{array}{l}\text { Aburizal Bakrie } \\
(11 \% \text { of TV) }\end{array}$ & Yes & $\begin{array}{l}\text { Self } \\
\text { Dahlan Iksan } \\
\text { (also SBY links) }\end{array}$ & $\begin{array}{l}\text { TVOne, ANTV, } \\
\text { Visi Media Asia, } \\
\text { Vivanews.com } \\
\text { (Anindya) } \\
\text { Jawa Pos Group } \\
\text { (Radar, TV network) }\end{array}$ & Yes (Golkar) \\
\hline $\begin{array}{l}\text { Susilo Bambang } \\
\text { Yudhoyono } \\
\text { (27\% of TV) }\end{array}$ & $\begin{array}{l}\text { Hidden } \\
\text { (Yes) }\end{array}$ & $\begin{array}{l}\text { Budi Sampoerna, } \\
\text { Sunaryo Sampoerna, } \\
\text { Ramadhan Pohan } \\
\text { Chairul Tanjung } \\
\text { James Riady } \\
\text { (Peter Gontha) }\end{array}$ & $\begin{array}{l}\text { Media Nusa } \\
\text { Pradana (Jurnal } \\
\text { Nasional) } \\
\text { Trans Corp (TransTV, } \\
\text { Trans 7), Detik.com } \\
\text { Lippo Media, } \\
\text { Berita Satu Media } \\
\text { Holdings (Suara } \\
\text { Pembaruan, Jakarta } \\
\text { Globe, Investor Daily, } \\
\text { BeritaSatu.com) }\end{array}$ & $\begin{array}{l}\text { Yes } \\
\text { (Democrat } \\
\text { Party) }\end{array}$ \\
\hline $\begin{array}{l}\text { Surya Paloh } \\
\text { ( } 36 \% \text { of TV) }\end{array}$ & Yes & Self & $\begin{array}{l}\text { MetroTV, } \\
\text { Media Indonesia }\end{array}$ & Yes (NasDem) \\
\hline Prabowo & Yes & $\begin{array}{l}\text { Self } \\
\text { Hashim (brother) }\end{array}$ & $\begin{array}{l}\text { Trying to buy } \\
\text { TV stations }\end{array}$ & Yes (Gerindra) \\
\hline Wiranto & Yes & $\begin{array}{l}\text { Self (Cendana?) } \\
\text { Hary Tanoesoedibjo } \\
\text { (had SBY links, } \\
\text { then Surya Paloh } \\
\text { links) }\end{array}$ & $\begin{array}{l}\quad-\overline{-} \\
\text { MNC Group, } \\
\text { RCTI, Global TV, } \\
\text { MNC TV, Sindo Radio, } \\
\text { Seputar Indonesia, } \\
\text { Okezone.com }\end{array}$ & Yes (Hanura) \\
\hline Megawati & Hidden & $\begin{array}{l}\text { Taufik Kiemas } \\
\text { Arifin Panigoro }\end{array}$ & - & Genetic (PDIP) \\
\hline Jusuf Kalla & Yes & Self & - & $\begin{array}{l}\text { Yes (Golkar } \\
2004,2014 ?)\end{array}$ \\
\hline
\end{tabular}

If one wants to win at this money-driven game-and not already an oligarch who commands a large personal fortune-one must get the financial backing of big Indonesian oligarchs who can supply the political cash. The risk parameters are 
sufficiently understood and anticipated by most oligarchs so that they supply funds strategically and "voluntarily." But sometimes persuasion is needed, often involving a strong element of extortion. Candidates and their backers threaten-implicitly or explicitly-to harass or punish oligarchs who refuse to provide financial support. Past or dormant legal cases can always be revived (for instance, to target Prabowo, President SBY suddenly backed an initiative to form an ad hoc body to investigate alleged human rights abuses perpetrated in 1998), and key business permits can suddenly be revoked or mysteriously require review. One of the most important political calculations an oligarch can make-and this is especially true for vulnerable ethnic Chinese oligarchs who have severely limited opportunities to augment their material power via the wealth-defense levers of office-is deciding which candidates to support and how much cash to supply. ${ }^{30}$

There is no shortage of illegality behind the major fortunes in Indonesia. This leaves oligarchs permanently vulnerable to being squeezed. Even if these oligarchs wanted to play strictly by institutionalized legal rules (and many of them probably do), this presumes that there are clear legal codes and procedures to follow in the first place. Such is not the case in Indonesia. This is partly because of outdated and contradictory laws dating back to Dutch colonial times, and partly a reflection of greater regional autonomy after 1998, which has resulted in conflicting laws across multiple jurisdictions (nowhere is this problem more prevalent than in the regulations and mappings covering land status, boundaries, ownership, and use).

But an equally important reason why there is so much legal disarray is that legal uncertainty plays a vital role in the constant game of extortion and forced-sharing that redistributes wealth among Indonesia's oligarchs and elites. The biggest game in town is not energetic wealth creation via industry and services, but aggressive wealth redistribution among the powerful after it has been extracted from the country's declining natural resource endowments. Oligarchs and politicians must master this game of money, elections, office, law, and extortion if they are to win (or just survive) in the country's challenging political economy. This is not a transient aspect of Indonesian politics that is likely to fade as the "quality of democracy" improves in the electoral cycles that lie ahead. Rather, it is a defining characteristic of how oligarchy and democracy are blended in contemporary Indonesia. And however much those playing the game at the top may complain about the distortions all of this causes for the nation's politics, or how disgusted they feel personally taking part in it, these relationships between the power of money and politics are deep and self-regenerating.

\section{Beyond Oligarchy?}

Recent work on oligarchs and oligarchy has generated welcomed debate, some of which is represented in this issue. One criticism, raised by Aspinall and by Caraway and Ford, is that oligarchic theory does not sufficiently emphasize politics from below and says very little about potentially important actors like activists, workers, and

\footnotetext{
${ }^{30}$ Another motivation mentioned by the oligarch seeking to launch a polling firm was to gain access to more reliable data about who was doing well to ensure funds were more effectively channeled to politicians who could be helpful or damaging to him. Confidential interview, Jakarta, July 14, 2012.
} 
unions. ${ }^{31}$ These authors do not seriously dispute the claim that the current distribution of power in Indonesia favors oligarchs and elites over much weaker, fragmented social forces. But they do advance the fairly uncontroversial observation that a comprehensive perspective on politics (of which oligarchic theory is a part) must incorporate all serious contenders for power. It is certainly true that dominance by a relatively small group of oligarchs and elites in one period hardly means these power positions are fixed.

It is noteworthy that neither my study of oligarchy (2011) nor that by Robison and Hadiz (2004) argues that other social forces are irrelevant, even if these other groups and actors are not the focus of these works. My own approach to oligarchy is explicitly grounded in power resource theory, which emphasizes power capacities ranging from the material resources of oligarchs to the mobilizational, coercive, and organizationalpositional power of other players. The distributions of these power resources are understood to vary both within and across cases. For instance, non-material power resources (including the mobilizational power of unions and parties) were vastly more important in Indonesia prior to the decline of Sukarno in the late 1960s. It was only after Suharto took over that oligarchic power arose and mobilizational power was systematically attacked and subverted. In my treatment of the United States case, I emphasize how the populist movement of the 1890s and early 1900s delivered major setbacks to oligarchs when a federal income tax exclusively targeting the ultra-rich was imposed twice-the second time by an enormous popular victory in the form of a constitutional amendment oligarchs resisted vigorously. Reading Aspinall and Caraway and Ford, one could get the mistaken impression that theorists of oligarchy believe oligarchs dominate everything everywhere, crowd out all other politics, and always win. Oligarchs not only lose many wealth-defense battles, but throughout history they have repeatedly been extinguished as a group. In the division of labor that is academia, it is fortunate that researchers analyze different elements of very complex political economies involving oligarchs, elites, states, warlords, students, activists, workers, and farmers. That said, scholars are not really engaging the work of their colleagues if their main criticism amounts to: You do not pay enough attention to the part I study.

The point of Oligarchy is to offer a re-theorization of oligarchs and oligarchy by excavating, refining, and partly redefining the concepts involved. Important facets of oligarchy-especially its many intersections and fusions with various forms of politics and rule-are developed in the book through multiple cases that overlap with Indonesia as often as they diverge from it. The justification of a book-length exploration focused on oligarchs is not the proposition that oligarchs are the only actors worthy of sustained attention. Rather, it is that the power of oligarchs is wildly disproportionate to their numbers (including in democracies), that there are specific political challenges oligarchs face inherent in the conflicts generated by extreme wealth

\footnotetext{
${ }^{31}$ Edward Aspinall, "Popular Agency and Interests in Indonesia's Democratic Transition and Consolidation," in this issue; Teri L. Caraway and Michele Ford, "Labor Unions and Electoral Contests in Democratic Indonesia," paper presented at "Beyond Oligarchy? Critical Exchanges on Accountability and Representation in Indonesia," the University of Sydney, December 14-15, 2012. Versions of these essays are slated for publication in a forthcoming volume on oligarchy in Indonesia from Cornell Southeast Asia Program Publications.
} 
stratification (and their position at the top rather than the bottom), and that concentrated material power manifests unique qualities that deserve careful and separate theorization. It is for these reasons, among others, that an understanding of oligarchs and oligarchy is not amenable to being folded into a generic "pluralist" optic of the sort Pepinsky advocates in this issue. ${ }^{32}$

Aspinall presents a second and rather different critique centered on how to interpret the collapse of the Suharto regime, the democratic transition, and the politics that followed. Going beyond the general call for keeping the analytical lens wide, he advances a much more specific claim that Indonesia's democratic transition in 1998 was driven from below. His argument is not merely that mass actions played a vital conclusive role in toppling a regime that was already damaged. It is that Suharto stepped down because of a political process he says was "society-initiated." The position Aspinall is critiquing acknowledges that societal forces played a role in the collapse of the New Order, but contends that activists and demonstrators followed and finished rather than led and initiated. This view posits that students in particular arose as a relatively inchoate "mobilization of the last minute" that took advantage of an already weakened regime reeling from the worst economic shock it had endured since the hyper-inflation of the 1960s, a regime that was badly fragmented from within and was less enthusiastically supported by foreign allies than at any time since Suharto came to power (with US Treasury Secretary Robert Rubin taking the lead in tightening the noose around the aging dictator's neck).

This interpretation argues that the financial crisis that erupted in 1997 was more destabilizing than past ruptures because the regime was less solidly backed by oligarchs and elites at home (including in the military) and strategic partners abroad. ${ }^{33}$ Students and other actors in civil society read the signals that Suharto was exposed and vulnerable-some communicated directly through players within the New Order regime. Pouring into the fissures opened by the financial crisis and the disarray at the top, emboldened students formed the backbone of a people-power moment that convinced Suharto to step aside. The popular moment was so weak and unthreatening, however, that after one of the twentieth century's most murderous and corrupt dictators concluded his impromptu resignation, he calmly went home, watched TV for several years in his living room, and eventually died in a hospital bed surrounded by family and cronies.

Aspinall's counter-argument is that powerful movements from below, which had been gaining strength and momentum since the early 1990s, split open the regime. This

\footnotetext{
${ }^{32}$ Across the decades, pluralism has come under sustained and effective criticism for its explanatory weaknesses when applied to cases like the United States. Pluralism lacks a sophisticated theory of the state and, by design, ignores material power rooted in social class. It is thus surprising to see calls for its transfer to Indonesia, where it promises to explain even less. The refashioned version of pluralism that Pepinsky wants to apply in Indonesia has its most important "interest group liberalism" component removed to better fit the Indonesian context. But the obvious question is: without this crucial element, what's left to apply? Compounding the problem is Pepinsky's effort to reduce the study of all politics and power to the analysis of policy outcomes.

${ }^{33}$ The financial crisis hit Indonesia particularly hard because the country was more exposed to the risks of highly mobile capital flows than in earlier decades and relative to other countries in the region. See Jeffrey A. Winters, "The Determinants of Financial Crisis in Asia," in The Politics of the Asian Economic Crisis, ed. T. J. Pempel (Ithaca, NY and London: Cornell University Press, 1999): 79-97.
} 
is not an easy interpretation to sustain. ${ }^{34}$ Although Aspinall grants that societal forces in Indonesia are chronically fragmented, he wants to credit them with constituting a mobilized movement that caused the cracks in the regime rather than took advantage of them. Curiously, he admits that the democratic transition immediately following Suharto's departure was dominated by elites and oligarchs rather than by societal forces. This suggests that the power position of civil society experiences unexplained oscillations. Thus, despite fragmentation, social forces were strong during the period leading up to 1997, and yet suddenly became weak during the transition years (which arguably should have been a period of triumph since the citizenry had just toppled a dictator). For reasons Aspinall does not explain, the disempowering effects of fragmentation were only temporary. Empowerment (despite chronic fragmentation) suddenly reappears in his approach to explain why Indonesia's oligarchs and elites do not win every political battle in the decade that follows. ${ }^{35}$

No one in this debate is arguing that forces from below were or are irrelevant. The fundamental question is whether it was a people-power movement or moment that pressured Suharto to abandon the presidency. For it to be a movement proper, we would have to see evidence of organization, networking, leadership, and some minimum of ideological coherence. These elements were scarcely present at the height of the mass actions, much less in the years leading up to 1998. A mobilization of the last minute-a people-power moment that is not the source of the regime's rupture, but which is cobbled together quickly to challenge an already weakened regime facing a crisis-is attainable even by fragmented social forces presented with an opening.

The various people assembled in protest in those months agreed on only one thing-that Suharto must go. Beyond that, there was very little consensus and a minimum of organization. Deep divisions were apparent almost immediately when one major student faction accepted the succession of Vice-President Habibie (because

\footnotetext{
${ }^{34}$ Pepinsky's argument that Suharto's regime collapsed because of conflicting "coalitions" of investors who disagreed over currency and other policy options as the regime was reeling from a financial crisis is equally difficult to sustain. First, if such coalitions existed, there is no evidence the members ever met, strategized, or were even aware they were in a coalition. Second, if there existed a faction or coalition of oligarchs still committed to maintaining Suharto's rule, it was at most a very tiny set of actors comprising his children, Bob Hasan, and perhaps a couple others like Liem Sioe Liong, who regularly met Suharto face-to-face (suggesting loyalty of a decidedly personal nature). There was far more unity than disagreement among oligarchs of all stripes that Suharto had to go. Even oligarchs who are nostalgic today for the "pre-kids era" under Suharto freely admit that they stood aside and did not come to his aid, financially or otherwise, as the New Order fragmented and crashed. The determining differences that resulted in the collapse of Suharto's regime in Indonesia and stability of Mahathir's regime in Malaysia, respectively, were not coalitional conflict or unity among investors, but rather the significant differences in oligarchic posture across the two cases, the scale of mass mobilization, and the decisive refusal of the military to defend Suharto in the Indonesian case. See Thomas Pepinsky, Economic Crises and the Breakdown of Authoritarian Regimes: Indonesia and Malaysia in Comparative Perspective (Cambridge: Cambridge University Press, 2009). For an illuminating treatment of military defection and the durability of authoritarian regimes, see Eva Bellin, "Reconsidering the Robustness of Authoritarianism in the Middle East: Lessons from the Arab Spring," Comparative Politics 44,2 (2012): 127-49.

${ }^{35}$ In the political struggles between oligarchs and mass groups, effective organization is vitally important for the latter to sustain its victories. When activists, workers, or peasants are unable to mobilize themselves, material power is dominant by default. As Huber and Stephens observe, "power resource theory assumes that property and organization are political power resources and that, in the absence of organization, political power resources will be highly asymmetrically distributed and political decisions will reflect the interests of property holders." Huber and Stephens, Democracy and the Left, p. 35.
} 
of his Islamic credentials), while another rejected him as a New Order leftover. It was into this crumbling people-power moment that the formidably empowered oligarchs and elites came forward to supplant revolusi with reformasi and redirect the democratic transition toward an electoral politics they could embrace and dominate. ${ }^{36}$

\section{Conclusions}

Wealth-power always matters in politics, democratic or otherwise. In many respects, the interplay of oligarchs, wealth, media, parties, and democracy in Indonesia displays increasing similarities with the expression of oligarchic power in democracies such as the United States (including extreme concentration in media ownership). The main differences-and they are important-are that civil society and the rule of law are vastly stronger in the latter. Strong legal regimes do a double service of constraining individual oligarchs while providing the primary firmament for property and wealth defense. The two functions are intimately related in the politics of oligarchy, and the absence of these conjoined elements accounts for why Indonesia is best described as an electoral ruling oligarchy (in which being an oligarch is closely intertwined with governing) rather than the civil type as in the United States or Singapore.

The trend is clear. As Indonesian democracy consolidates, oligarchs are increasingly positioned as key arbiters of the country's political life. Their grip is particularly evident in the structure and operation of political parties-including oligarchic control over who can rise as contenders for party leadership, who can run for major offices, and how the political apparatus is used for purposes of wealth defense. Insofar as the media are heavily dominated by the same actors and political forces, it is unlikely that a critical free press or parties will provide the venues or vehicles for challenging this particular form of oligarchic domination. As for the potential of law to constrain oligarchs in the near or medium term, the prospects are equally grim. There is an expectation in the scholarly literature that as democratic consolidation progresses, gains will be made in the rule of law (typically portrayed as a "quality of democracy" matter). But there is no inherent reason for this to be so. A democracy thoroughly captured by oligarchs has no strong inherent incentives to impose independent and punishing legal constraints on itself. Nor is democracy necessarily unstable or vulnerable to crippling illegitimacy just because the legal regime is feeble at the top. Evidence from a broad sample of transitions to democracy globally suggest that "democracy without law" can persist for decades. It is a scenario Indonesia has been playing out since 1998.

\footnotetext{
${ }^{36}$ In his critique of "leaderless" revolutions, Berkeley sociologist Cihan Tugal warns against the "fallacy that the people can take power without an agenda, an alternative platform, an ideology, and leaders." He continues: "Those who cannot represent themselves will be represented. This old statement regarding the French peasantry warns us against the beautification of non-organized masses, a romanticization now in high fashion. Multiple anti-representation theses from rival ideological corners (anarchist, liberal, autonomist, postmodernist, etc.) all boil down to the following assumption: when there is no metadiscourse and no leadership, plurality will win." If this assumption is true at all, Tugal suggests, it holds only in the short run. See Cihan Tugal, "The End of the 'Leaderless' Revolution," Counterpunch, July 10, 2013, at http:// www.counterpunch.org/2013/07/10/the-end-of-the-leaderless-revolution/, accessed on July 31, 2013.
} 